A. Shepel ${ }^{4}, \mathrm{PhD}$ (Agri.), Assoc. Prof.;

${ }^{1}$ National University of Life and Environmental Sciences of Ukraine,

17 Heroiv Oborony Str., Kyiv, 03041 Ukraine;

${ }^{2}$ LLC Lotivka Elit, Khmelnitsky, Ukraine;

${ }^{3}$ Taras Shevchenko National University of Kyiv, Institute of Geology, 90 Vasylkivska Str., Kyiv, 03022 Ukraine;

${ }^{4}$ Kherson State Agrarian University, Kherson, Ukraine

\title{
SILICON CONTENT, PHYSICAL AND CHEMICAL PROPERTIES OF SOILS OF THE KHMELNYTSKY REGION OF UKRAINE
}

\begin{abstract}
(Представлено членом редакційної колегії д-ром геол. наук, проф. С.А. Вижвою)
Silicon plays the significant role in the growth and development of plants, their resistance to stress conditions. However, there is limited research on the content of various forms of silicon in soils, the relationship with soil cations, which is particularly relevant in the context of intensive agriculture and climate aridization in Ukraine. The purpose of the present study was to determine the content of silicon compounds of different mobility in the arable soils of the Khmelnytsky region, the spatial variation of these parameters, and to detect the dependence between the content of silicon compounds and soil particle size. The study was performed at the area of LLC "Lotivka Elit" of Shepetivka district of Khmelnitsky region in field crop rotation. We determined for soil samples: particle size distribution and content of fractions of granulometric elements of different sizes, $\mathrm{pH}$ of salt extraction $(1,0 \mathrm{M} \mathrm{KCl}$ solution), humus content, calcium and magnesium exchangeable compounds by extraction with $1,0 \mathrm{M} \mathrm{KCl} \mathrm{solution.} \mathrm{The}$ results showed that the content of silicon compounds in soils depends on the particle size distribution of soil, the value of exchangeable acidity, humus content, and the composition of exchangeable cations.

Keywords: silicon, soil cations, soil reaction, exchangeable cations, soil texture.
\end{abstract}

Introduction. The special attention require the soil studies in Ukraine in the current conditions of agrarian reform and the introduction of the agricultural land market in Ukraine. In recent years, agrarians in Ukraine have noted the direct impact of global warming on crop is increasing and expanding. The study of soil nutrient regimes is of the great importance. However, there is a limited amount of the research of the individual elements, including silicon. That is why our aim was to study the content of silicon compounds of different mobility in soils and its correlation with indicators of soil physicochemical properties.

State of the art. Silicon (Si) is the second most prevalent crust mineral and occupies $27,6 \%$ of the crust mass. Its role in soils and plants is not well understood (Matychenkov, 2008). Its concentration in soils varies greatly from less than $1 \%$ to more than $45 \%$. The main factor influencing this is the parent material, but it is important to study other factors of influence: climate, plants, the land use (Landré et al., 2020). Silicon is a widespread and differentially distributed element in soils that has important biological functions. However, the content of silicon differs in different crops due to their ability to use this element (Rios et al., 2017).

A number of studies (Coskun et al., 2016; Ranjbar et al., 2019) have established the role of silicon in growth and development of plants, their resistance to stress conditions, including salinity and drought. The use of Si reduced stress in soil salinization by reducing the absorption of sodium cation and improving feed efficiency, thereby increasing plant dry matter in sorghum by $27 \%$ and sunflower by $41 \%$. This occurred when Si was applied either by root application or by a combination of root and root application respectively. The use of Si can permanently reduce the harmful effects of salt stress and increase the yield of sorghum and sunflower plants (Hurtado et al., 2019).

The number of studies note the importance of silicon in the face of global climate change. The silicon content of plants can vary greatly between plants and perform different roles and functions in plant biology (Katz, 2019). The content of silicon in soils depends on the reaction of the soil environment. The alkalinity of the soil adversely affects the growth and development of agricultural plants, and therefore studies on the effects of exogenous silicon ( $\mathrm{Si}$ ) and salicylic acid (SA) on plants (Khan et al., 2019). Plants treated with silicon formulations had formed larger biomass, had higher biomass content and a better root system than the control plants. Silicon preparations counteracted the oxidative damage of alkaline stress, reducing the accumulation of reactive oxygen species and lipid peroxidation. Silicon improves alkaline stress resistance in tomato seedlings, modifying the content of endogenous $\mathrm{Na}^{+}$and $\mathrm{K}^{+}$, regulating oxidative damage and key genes, and modulating endogenous hormone levels.

Recently, a number of studies considered the modern approaches of soil properties estimation (Mank et al., 2019; Tonkha et al., 2017, 2018). The studies require the adaptation of land management investigations (Khmelovskyi et al., 2019) and implementation of coordinated agroforestry activities. Among the rapid methods of the investigation of thermal transformations is the temperature programmed desorption mass spectrometry (Palianytsia et al., 2014). According to (Bobos et al., 2019), the density of the plants significantly influenced the economically valuable indicators, because there is always competition for light, moisture and nutrients between plants in the life process.

Magnetic method is the low cost and time saving technology to study soil properties (Gadirov et al., 2018; Menshov et al., 2016, 2020; Menshov abd Sukhorada, 2018), to assess soil erosion and degradation (Menshov, 2016). The study (Menshov et al., 2018), showed a strong correlation between the magnetic susceptibility (MS) and the erosion index. MS and the erosion index were found to correlate with the humus content (Kruglov et al., 2018). Environmental magnetic studies require the attracting of the evidence from the related fields to improve the methodology of the research (Tabachenko et al., 2016; Dychkovskyi et al., 2020; Lozynskyi et al., 2020).

Thus, the studies of the role of silicon in the growth and development of plants, their resistance to stress conditions are of the great importance. That is why studies of the content of various forms of silicon and their relationship with soil cations under climate aridization are relevant. 
Methods. The purpose of the research was to determine the content of silicon compounds of different mobility in the arable soils of the Khmelnytsky region. We determined the spatial variation of the parameters, evaluated the dependence between the content of silicon compounds and soil particle size (soil texture). Finally, we detected content of exchangeable bases of calcium and magnesium.

The experiment was performed in the fields of LLC "Lotivka Elit" of Shepetivka district of Khmelnitsky region close to the settlement of Mokiyivka. The study area is field crop rotation: corn for grain - soybean - winter wheat - corn for grain - pea. The soils of the territory are dark grey forest and chernozems podzolized light- and medium-loamy on loesses. Soils are characterized by good fertility rates. The humus content in the upper horizon reaches 3,0-3,5\%. The availability of mobile phosphorus compounds is medium and high and mobile potassium compounds are high. The natural development of the processes of podzolization and agricultural use of soils with applying of high doses of nitrogen fertilizers leads to a decrease in the reaction of the soil solution to slightly acidic, and in some places - medium acidic values.

Soils were sampled from the arable horizon, from a depth of $0-25 \mathrm{~cm}$, the amount is 30 soil samples, and the distribution of soil samples was random. Soil samples were collected in accordance with ISO 10381-2. Preparation for chemical analysis was performed according to DSTU ISO 11464-2001.

The soil samples analysis included: particle size distribution and content of fractions of granulometric elements of different sizes determination according to DSTU 4730:2007; $\mathrm{pH}$ of salt extraction $(1,0 \mathrm{M} \mathrm{KCl}$ solution) according to DSTU ISO 10390:2001; humus content according to DSTU 4289:2004; content of calcium and magnesium exchangeable compounds by extraction with $1,0 \mathrm{M} \mathrm{KCl}$ solution. Silica compounds in soils were determined by Mallen and Riley's method with silicon extraction (Titova et al., 2011). This method allows determining the content of monosilicic acids in the soil. Two types of extraction solutions were used to determine the varying degrees of accessibility of the silica compounds: readily available (actual) silicon was determined by $0,01 \mathrm{M} \mathrm{CaCl}_{2}$ extraction, hard-soluble (potential) silicon was determined by $0,1 \mathrm{M} \mathrm{HCl}$ extraction, in a soil: solution ratio $1: 10$, time interaction of soils with extraction solutions was 1 hour.

Results and discussion. The annual uptake of silicon by crops is more than 200 million tons in the world, which leads to a decrease in the concentration of silicon available to plants, especially in the arable layer of soils used in agriculture (Titova et al. 2011). There are only several case studies to evaluate the content and dynamics of silicon compounds, their relationship with other elements in soils of agricultural use, especially in soils of medium and heavy texture.

The analyzed soil samples were grouped by the content of the fraction of "physical clay", particle size less than 0,01 $\mathrm{mm}$, in the following groups: less than $25,0 \%, 25,0-29,9 \%$, $30,0-34,9 \%, 35,0-39,9 \%$ of physical clay content. Among the samples tested, the largest amount contained more than $30,0 \%$ of the particles of physical clay. The most of studied samples belong to the medium loamy texture. For each group of samples the average values of the studied parameters are deduced. The deviations, which are presented in relative percentages, are calculated. We assume that if the deviation of the individual values from the average is less than $30 \%$, then it is possible to make high reliability conclusions about the regularities and relationships between the indicators.

Soils of the Mokiyivtsi area have an average $\mathrm{pH}$ of 4,95,4 , the acidity of these soils decreases with increasing content of physical clay (see Table 1).

Granulometric composition and physical and chemical properties of the investigated soils of the Khmelnytsky region, Shepetivka district, Mokiyivtsi area, mean values and standard deviations

\begin{tabular}{|c|c|c|c|c|c|c|c|c|c|c|c|c|c|}
\hline \multirow{3}{*}{ 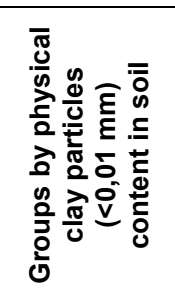 } & \multirow{3}{*}{  } & \multicolumn{6}{|c|}{ Content of granulomentric particles of different sizes } & \multirow{2}{*}{\multicolumn{2}{|c|}{$\begin{array}{c}\text { pH, salt } \\
\text { extraction }\end{array}$}} & \multirow{2}{*}{\multicolumn{2}{|c|}{$\begin{array}{c}\text { Humus } \\
\text { content, \% }\end{array}$}} & \multirow{2}{*}{\multicolumn{2}{|c|}{$\begin{array}{c}\text { Content of sum } \\
\text { of exchangeable } \\
\text { bases } \mathrm{Ca}+\mathrm{Mg} \text {, } \\
\mathrm{mmol} / 100 \mathrm{~g} \mathrm{soil}\end{array}$}} \\
\hline & & \multicolumn{2}{|c|}{$<0,01 \mathrm{~mm}, \%$} & \multicolumn{2}{|c|}{$<0,005 \mathrm{~mm}, \%$} & \multicolumn{2}{|c|}{$<0,001 \mathrm{~mm}, \%$} & & & & & & \\
\hline & & 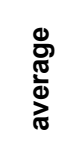 & 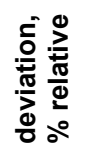 & 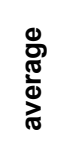 & 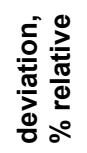 & 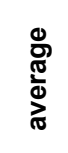 & 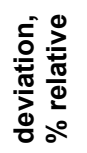 & 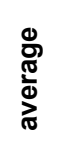 & 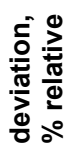 & $\frac{\stackrel{0}{0}}{\sum_{0}^{\frac{\pi}{0}}}$ & 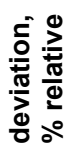 & 离 & 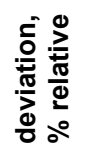 \\
\hline$<25,0 \%$ & 4 & 20,8 & 10 & 17,7 & 12 & 13,2 & 17 & 4,9 & 16 & 2,1 & 29 & 6,3 & 33 \\
\hline $25,0-29,9 \%$ & 4 & 26,8 & 8 & 22,0 & 15 & 15,7 & 18 & 4,9 & 14 & 2,1 & 33 & 8,3 & 19 \\
\hline $30,0-34,9 \%$ & 12 & 32,0 & 5 & 26,6 & 5 & 19,5 & 8 & 5,2 & 8 & 2,9 & 21 & 11,6 & 17 \\
\hline $35,0-39,9 \%$ & 10 & 36,6 & 4 & 30,6 & 8 & 22,0 & 6 & 5,4 & 7 & 3,3 & 15 & 13,2 & 19 \\
\hline
\end{tabular}

The average values of humus content in soils of the Mokiyivtsi area increases from 2,1 to $3,3 \%$, and a positive correlation of this indicator with the content in the soil of physical clay particles is observed.

The content of the sum of the exchangeable bases of calcium and magnesium in the soils of the studied area increases with the increasing of content of the physical clay fraction.

The average values of readily available silicon content in the studied soils range from 51 to $92 \mathrm{mg} / \mathrm{kg} \mathrm{SiO} 2$ (Table 2). But in the soils of this area there is a slight tendency to increase the content of readily available silicon with increasing content of physical clay in soil. But these soils are characterized by high deviations of individual values from the average (up to $90 \%$ ). In our opinion, this tendency is also associated with a decrease in the acidity of the soil solution in the soil of this area and increasing of content of calcium and the amount of exchangeable bases in soils.
The dependence of change in the content of silicon compounds from the particle size distribution and the content of calcium and magnesium bases is better observed for the fraction of hard-soluble silicon in soils of the studied area. Average values of hard-soluble silicon in soils of Mokiyivtsi area increased from 326 to $570 \mathrm{mg} / \mathrm{kg} \mathrm{SiO}$, and deviations of individual samples from average didn't exceed $30 \%$ (Table 2).

The dependence of change of the content of silicon compounds from the particle size distribution and the content of calcium and magnesium bases is observed for the fraction of hard-soluble silicon in soils of the studied area. Average values of hard-soluble silicon in soils of Mokiyivtsi area increased from 326 to $570 \mathrm{mg} / \mathrm{kg} \mathrm{SiO}$, and deviations of individual samples from average didn't exceed $30 \%$ (see Table 2). 
Content of exchangeable calcium and magnesium cations, and silicon compounds

Table 2 of different fractions in soils of Khmelnytsky region, Shepetivka district, Mokiivtsi area

\begin{tabular}{|c|c|c|c|c|c|c|c|c|c|c|c|}
\hline \multirow{2}{*}{$\begin{array}{l}\frac{\pi}{d} \\
\frac{1}{4}\end{array}$} & \multirow{2}{*}{$\begin{array}{c}\text { Groups } \\
\text { by physical } \\
\text { clay particles } \\
(<0,01 \mathrm{~mm}) \\
\text { content in soil }\end{array}$} & \multirow{2}{*}{ 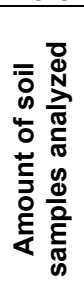 } & \multicolumn{2}{|c|}{$\begin{array}{c}\text { Exchangeable } \\
\text { Calcium content, } \\
\text { Ca, mg/kg }\end{array}$} & \multicolumn{2}{|c|}{$\begin{array}{c}\text { Exchangeable } \\
\text { Magnesium } \\
\text { content, Mg, } \\
\text { mg/kg }\end{array}$} & \multicolumn{2}{|c|}{$\begin{array}{l}\text { Readily-available } \\
\text { silicon content, } \\
\mathrm{SiO}_{2}, \mathrm{mg} / \mathrm{kg}\end{array}$} & \multicolumn{2}{|c|}{$\begin{array}{l}\text { Hard-soluble } \\
\text { silicon } \\
\text { content, } \\
\mathrm{SiO}_{2}, \mathrm{mg} / \mathrm{kg} \\
\end{array}$} & \multirow{2}{*}{$\begin{array}{c}\text { Ratio } \\
\text { Ca exchangeable/ } \\
\mathrm{SiO}_{2} \text { hard-soluble., } \\
\text { based on averages }\end{array}$} \\
\hline & & & 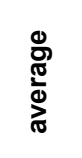 & 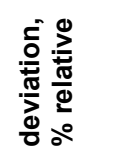 & 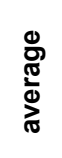 & 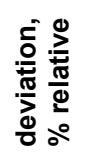 & 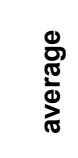 & 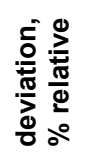 & 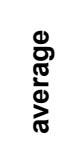 & 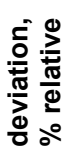 & \\
\hline \multirow{4}{*}{$\frac{\sum_{i}^{\infty}}{\sum_{\bar{x}}^{\frac{5}{2}}}$} & $<25,0 \%$ & 4 & 1000 & 34 & 157 & 50 & 51 & 90 & 326 & 13 & 3,1 \\
\hline & $25,0-29,9 \%$ & 4 & 1330 & 24 & 195 & 9 & 60 & 53 & 405 & 19 & 3,3 \\
\hline & $30,0-34,9 \%$ & 12 & 1990 & 18 & 205 & 27 & 68 & 63 & 502 & 25 & 4,0 \\
\hline & $35,0-39,9 \%$ & 10 & 2290 & 20 & 165 & 28 & 92 & 65 & 570 & 22 & 4,0 \\
\hline
\end{tabular}

The results have shown that the behavior of silicon compounds in soils is influenced by the particle size distribution of the soil, as well as by the composition and content of the exchangeable cations. The content of exchangeable cations in the soil depends largely on the calcium content. We studied the relation between exchangeable calcium and hard-soluble silicon compounds in soil. The average calcium content of the studied soils is 1000$2290 \mathrm{mg} / \mathrm{kg}$ of Ca. The average values of the content of hardsoluble silicon are $326-570 \mathrm{mg} / \mathrm{kg}$ in terms of $\mathrm{SiO}_{2}$. The content of these compounds of silicon in the soil is $3,1-4,0$ times lower than the content of calcium. There is a tendency of increasing of the $\mathrm{Ca} / \mathrm{SiO}_{2}$ ratio with an increase of physical clay content in the soils of the Makiyivtsi area (Table 2).

We proposed to evaluate the level of balance of silicon compounds in agricultural lands by the content of readily available (actual) and hard-soluble (potential) silicon according to (Titova et al., 2011). The mean values of readily available (actual) silicon of $21-40 \mathrm{mg} / \mathrm{kg} \mathrm{SiO} 2$ and $301-$ $600 \mathrm{mg} / \mathrm{kg} \mathrm{SiO} 2$ of hard-soluble (potential) silicon by this graduation are attributed to the low deficit of silicon, and values higher than $40 \mathrm{mg} / \mathrm{kg} \mathrm{SiO}$ readily available and higher than $600 \mathrm{mg} / \mathrm{kg} \mathrm{SiO}$ hard-soluble mean no deficit silicon balance.
When evaluating the silicon balance by the specified graduation, we observe that the investigated soils of the Khmelnytsky region have mainly low-deficient silicon balance, both of readily-available and hard-soluble forms. However, individual samples of the Mokiyivtsi area have an average deficiency of silicon, in particular if the evaluation is carried out on the content of readily available (actual) silicon compounds in the arable layer of the studied soils.

According to the field studies of the microrelief as well as the content of silicon, physicochemical properties, we attracted the data form the Mokiivtsiarray. The different features of the relief were analyzed.

The field M3-06 has almost flat surface, the height difference in the studied area is not more than $2 \mathrm{~m}$ per $1000 \mathrm{~m}$ of length (Fig. 1).

The point M3-06-21 is on the most elevated level section when the point M3-06-09 is in a small depression between two rises. The content of physical clay (particles $<0,01 \mathrm{~mm}$ ) at these points is $32,7-32,4 \%$, the difference is insignificant. The content of the sum of cations of calcium and magnesium between points differs up to $1,7 \mathrm{mmol} / 100 \mathrm{~g}$ or $16,5 \%$ relative. The content of silicon compounds extracted with $0,1 \mathrm{M} \mathrm{HCl}$ at these points is 350 and $714 \mathrm{mg} / \mathrm{kg}$. The difference is $364 \mathrm{mg} / \mathrm{kg}$ or $52,4 \%$ relatively (see Table 3 ).

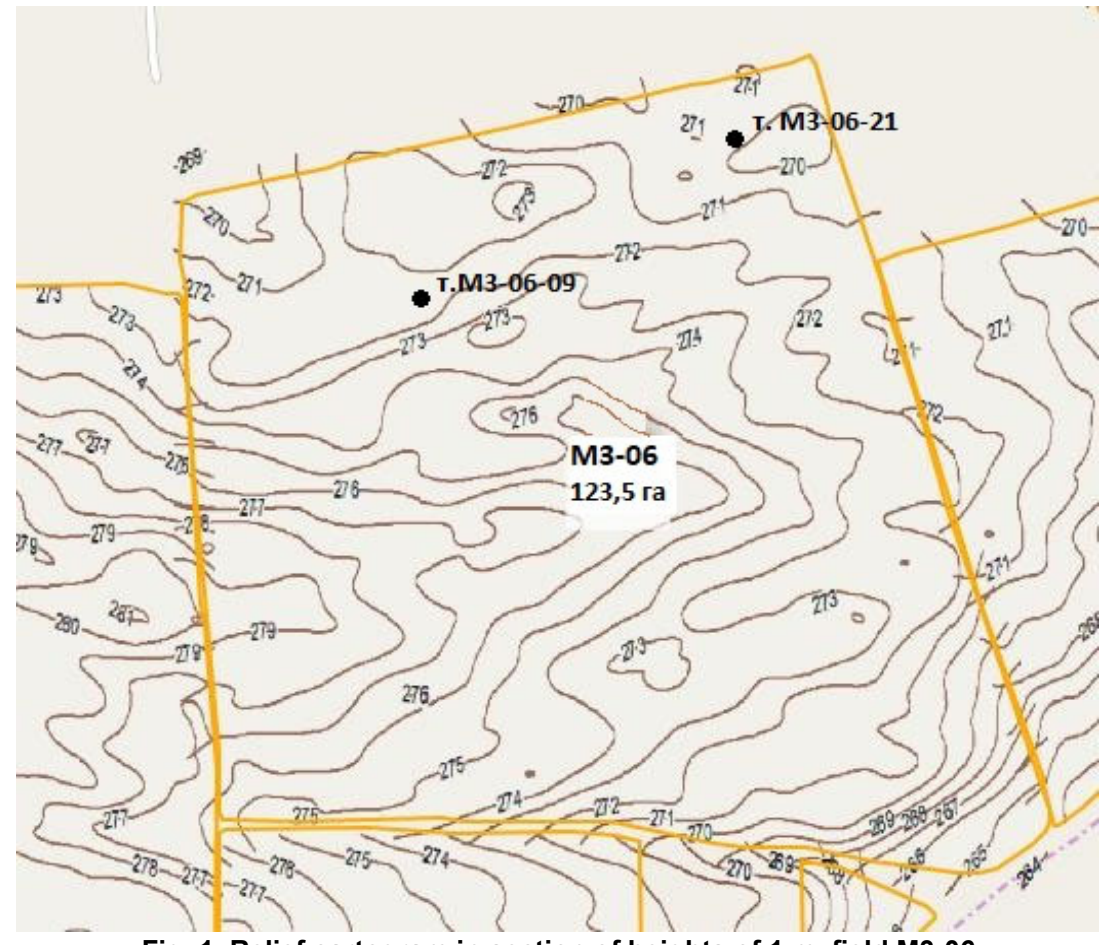

Fig. 1. Relief cartogram in section of heights of $1 \mathrm{~m}$, field M3-06 
Physico-chemical properties of the soil and the content of silicon compounds of different solubility of the points of selection according to the relief cartograms

\begin{tabular}{|c|c|c|c|c|c|c|c|}
\hline $\begin{array}{l}\text { Code } \\
\text { of field }\end{array}$ & $\begin{array}{l}\text { Code } \\
\text { of point }\end{array}$ & $\mathrm{pH} \mathrm{H}_{2} \mathrm{O}$ & $\begin{array}{c}\text { Humus } \\
\text { content, \% }\end{array}$ & $\begin{array}{c}\text { Content of particles } \\
<0,01 \mathrm{~mm} \text { in soil texture }\end{array}$ & $\begin{array}{c}\mathrm{Ca}+\mathrm{Mg}, \\
\mathrm{mmol} / 100 \mathrm{~g}\end{array}$ & $\begin{array}{c}\mathrm{SiO}_{2}, \mathrm{CaCl}_{2} \\
\text { extraction, } \\
\text { ppm }\end{array}$ & $\begin{array}{c}\mathrm{SiO}_{2}, \mathrm{Hcl} \\
\text { extraction, } \\
\text { ppm }\end{array}$ \\
\hline M3-06 & M3-06-09 & 6,5 & 3,5 & 32,4 & 12,0 & 72 & 714 \\
\hline M3-06 & M3-06-21 & 6,0 & 2,7 & 32,7 & 10,3 & 56 & 350 \\
\hline M8-03 & M8-03-09 & 6,3 & 2,8 & 33,9 & 12,3 & 319 & 694 \\
\hline M8-03 & M8-03-32 & 5,8 & 3,1 & 35,1 & 13,5 & 92 & 186 \\
\hline
\end{tabular}

The next field M8-03 is characterized by much higher dissected relief, has a slope in the north-eastern direction with a height difference of $18 \mathrm{~m}$ by $1000 \mathrm{~m}$ in length (Fig. 2). The point M8-03-32 is located on a steeper section of the slope, where the height difference is up to $4 \mathrm{~m}$ by 50 lengths, i.e. the slope is about 4,5-5. Point M8-03-09 is located at the gentler section of the slope, with a concave shape of the microrelief, the slope steepness does not exceed $2^{\circ}$.
According to the content of physical clay, these points have similar values $(33,9-35,1 \%)$. The content of the sum of cations of calcium and magnesium differs up to $1,2 \mathrm{mmol} / 100$ or $8,8 \%$ relative. The content of silicon compounds extracted with $0,1 \mathrm{M} \mathrm{HCl}$ at these points is 186 and $694 \mathrm{mg} / \mathrm{kg}$, the difference is $508 \mathrm{mg} / \mathrm{kg}$ or $73,2 \%$ relatively in favor of a point that is within the concave shape of the terrain (see Table 3).

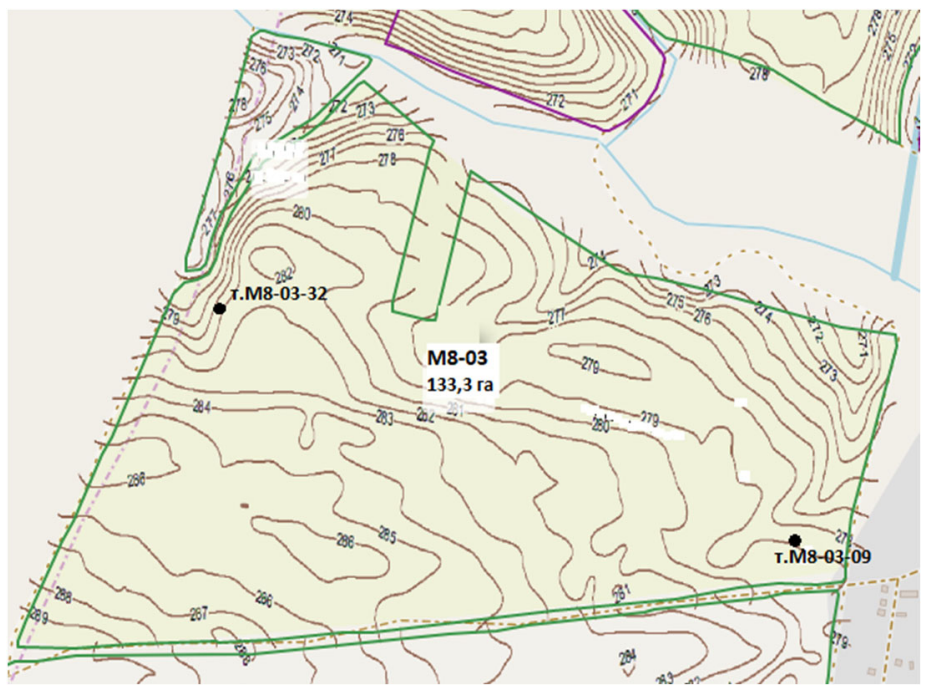

Fig. 2. Relief cartogram in section of heights of $1 \mathrm{~m}$, field M8-03

Conclusions. The average values of the content of readily-soluble silicon compounds in the investigated light loamy and medium loamy soils of agricultural lands of Khmelnitsky region Shepetivka district Mokiyivtsi area range from 51 to $92 \mathrm{mg} / \mathrm{kg} \mathrm{SiO}$, and the content of soluble compounds is $326-570 \mathrm{mg} / \mathrm{kg}$ of $\mathrm{SiO}_{2}$.

The results have shown that the content of silicon compounds in soils are related to the particle size distribution of the soil, the value of the exchangeable acidity, the content of humus, and the composition and content of exchangeable cations. The considered cases show that the content in the soil of silicon extracted with $0,1 \mathrm{M} \mathrm{HCl}$ depends on the features of the microrelief, can be an indicator of accumulative and erosion processes, and is the parameter that varies more intensely compared to the particle size distribution and content of calcium exchange cations and magnesium. This statement needs further research.

Acknowledgment. This study was supported by the Ministry of Education and Science of Ukraine as apart of research projects \#110/4-пр-2020 of National University of Life and Environmental Sciences of Ukraine as well as \#18БП04901 of Taras Shevchenko National University of Kyiv.

Список використаних джерел

Круглов, О, Меньшов, О., Улько, Є, Кучер, А, Назарок, П. (2018) Індикація ерозійних процесів у грунтовому покриві Харківської області за магнітними даними. Вісник Київського національного університету імені Тараса Шевченка. Геологія, 82(3), 36-44.

Матыченков, В.В. (2008). Роль подвижных соединений кремния в растениях и системе почва-растение. Авторефр. дис. ... д-ра. биол. наук. Пущино.

Меньшов, О., Сухорада, А. (2017). Основи теорії та методології геофізики ґрунтового покриву: перші результати практичного застосування.
Вісник Київського національного університету імені Тараса Шевченка. Геологія, 79(4), 35-39.

Меньшов, О., Кудеравець, Р., Попов, С., Хоменко, Р., Сухорада, А., Чоботок, І. (2016) Термомагнітний аналіз ґрунтів територій покладів вуглеводнів. Вісник Київського національного університету імені Тараса Шевченка. Геологія, 73(2), 33-37.

Меньшов, О.І. (2016). Застосування магнітних методів для контролю змін продуктивних земель. Геофізичний журнал, 38(4), 130-137.

Титова, В.И., Дабахова, Е.В., Дабахов, М.В. (2011). Агро-и биохимические методы исследования состояния экосистем: учеб. пособие для вузов. Н. Новгород: Изд-во ВВАГС, 73-84.

Тонха, ОЛ., Балаєв, А.Д., Піковська, О.В. (2017). Формування мікробного комплексу чорнозему реградованого за різних систем удобрення. Науковий журнал "Рослинництво та грунтознавство", (269), 148-153.

Bobos, I., Zavadska, O., Tonha, O., Olt, J., Fedosy, I. (2019). Optimization of plant densities of dolichos (dolichos lablab L. var. lignosus) bean in the Right-bank of Forest-steppe of Ukraine. Agronomy Research, 17(6), 2195-2202.

Coskun, D., Britto, D.T., Huynh, W.Q., Kronzucker, H.J. (2016). The role of silicon in higher plants under salinity and drought stress. Frontiers in Plant Science, 7, 1072.

Dychkovskyi, R., Shavarskyi, la., Saik, P., Lozynskyi, V., Falshtynskyi, V., Cabana, E. (2020). Research into stress-strain state of the rock mass condition in the process of the operation of double-unit longwalls. Mining of Mineral Deposits, 14(2), 85-94. https://doi.org/10.33271/mining14.02.085

Gadirov, V.G., Eppelbaum, L.V., Kuderavets, R.S., Menshov, O.I., Gadirov, K.V. (2018). Indicative features of local magnetic anomalies from hydrocarbon deposits: examples from Azerbaijan and Ukraine. Acta Geophysica, 66(6), 1463-1483.

Hurtado, A.C. Chiconato, D.A., de Mello Prado, R., Junior, G.D.S.S. Felisberto, G. (2019). Silicon attenuates sodium toxicity by improving nutritional efficiency in sorghum and sunflower plants. Plant Physiology and Biochemistry, $142,224-233$

Katz, O. (2019). Silicon content is a plant functional trait: implications in a changing world. Flora, 254, 88-94.

Khan, A., Kamran, M., Imran, M., Al-Harrasi, A., Al-Rawahi, A., Al-Amri, I.,

\& Khan, A. L. (2019). Silicon and salicylic acid confer high-pH stress tolerance in tomato seedlings. Scientific Reports, 9(1), 1-16.

Khmelovskyi, V., Rogach, S., Tonkha, O., Rosamaha, Y. (2019). Quality evaluation of mixing fodder by mobile combined units. Engineering for Rural Development, 18, 299-304. 
Landré, A., Cornu, S., Meunier, J. D., Guérin, A., Arrouays, D., Caubet, M., Saby, N. P. A. (2020). Do climate and land use affect the pool of total silicon concentration? A digital soil mapping approach of French topsoils. Geoderma, 364, 114-175

Lozynskyi, V., Medianyk, V., Saik, P., Rysbekov, K., Demydov, M. (2020). Multivariance solutions for designing new levels of coal mines. Rudarsko Geolosko Naftni Zbornik, 35(2), 23-32. https://doi.org/10.17794/rgn.2020.2.3 Mank, V., Tonkha, O., Galimova, V., Surovtsev, S., Menshov, O., Bukova, O. Rogovskiy, I. (2019). Electrochemical investigation of cobalt absorbtion processes by soils of Ukraine Visnyk of Taras Shevchenko National University of Kyiv. Geology, 86(3), 34-39.

Menshov, O., Spassov, S., Camps, P., Vyzhva, S., Pereira, P., Pastushenko, T., Demidov, V. (2020). Soil and dust magnetism in semi-urban area Truskavets, Ukraine. Environmental Earth Sciences, 79, 1-10.

Menshov, O., Kruglov, O., Vyzhva, S., Nazarok, P., Pereira, P. Pastushenko, T. (2018). Magnetic methods in tracing soil erosion, Kharkov Region, Ukraine. Stud. Geophys. Geod., 62, 681-696.

Palianytsia, B., Kulik, T., Dudik, O., Cherniavska, T., Tonkha, O. (2014). Study of the thermal decomposition of some components of biomass by desorption mass spectrometry. International Congress on Energy Efficiency and Energy Related Materials (ENEFM2013), Springer, Cham, 19-25.

Ranjbar, S.S., Motesharezadeh, B., Moshiri, F., Hosseini, H.M., Alikhani, H.A. (2019). Silicon Utilization Efficiency of Different Wheat Cultivars in a Calcareous Soil. Silicon, 11(4), 2159-2168.

Rios, J.J., Martínez-Ballesta, M.C., Ruiz, J.M., Blasco, B., Carvajal, M (2017). Silicon-mediated improvement in plant salinity tolerance: the role of aquaporins. Frontiers in plant science, 8, 948

Tabachenko, M., Saik, P., Lozynskyi, V., Falshtynskyi, V., Dychkovskyi R. (2016). Features of setting up a complex, combined and zero-waste gasifier plant. Mining of Mineral Deposits, 10(3), 37-45. http://dx.doi.org/ 10.15407/mining 10.03 .037

Tonkha, O.L., Sychevskyi, S.O., Pikovskaya, O.V., Kovalenko, V.P (2018). Modern Approach In Farming Based On Estimation Of Soil Properties Variability. 12th International Conference on Monitoring of Geological Processes and Ecological Condition of the Environment.

\section{References}

Bobos, I., Zavadska, O., Tonha, O., Olt, J., Fedosy, I. (2019). Optimization of plant densities of dolichos (dolichos lablab L. var. lignosus) bean in the Right-bank of Forest-steppe of Ukraine. Agronomy Research, 17(6), 2195-2202.

Coskun, D., Britto, D.T., Huynh, W.Q., Kronzucker, H.J. (2016). The role of silicon in higher plants under salinity and drought stress. Frontiers in Plant Science, 7, 1072

Dychkovskyi, R., Shavarskyi, la., Saik, P., Lozynskyi, V., Falshtynskyi, V., Cabana, E. (2020). Research into stress-strain state of the rock mass condition in the process of the operation of double-unit longwalls. Mining of Mineral Deposits, 14(2), 85-94. https://doi.org/10.33271/mining14.02.085

Gadirov, V.G., Eppelbaum, L.V., Kuderavets, R.S., Menshov, O.I., Gadirov, K.V. (2018). Indicative features of local magnetic anomalies from hydrocarbon deposits: examples from Azerbaijan and Ukraine. Acta Geophysica, 66(6), 1463-1483.

Hurtado, A.C., Chiconato, D.A., de Mello Prado, R., Junior, G.D.S.S., Felisberto, G. (2019). Silicon attenuates sodium toxicity by improving nutritional efficiency in sorghum and sunflower plants. Plant Physiology and Biochemistry, 142, 224-233

Katz, O. (2019). Silicon content is a plant functional trait: implications in a changing world. Flora, 254, 88-94

Khan, A., Kamran, M., Imran, M., Al-Harrasi, A., Al-Rawahi, A., Al-Amri, I.,

Khan, A. L. (2019). Silicon and salicylic acid confer high-pH stress tolerance in tomato seedlings. Scientific Reports, 9(1), 1-16.
Khmelovskyi, V., Rogach, S., Tonkha, O., Rosamaha, Y. (2019). Quality evaluation of mixing fodder by mobile combined units. Engineering for Rural Development, 18, 299-304

Kruglov, O., Menshov, O., Ulko, E., Kucher, A., Nazarok, P. (2018). Soil erosion indication by magnetic methods in Kharkiv region. VisnykofTarasShevchenkoNationalUniversityofKyiv. Geology, 82(3), 36-44. [in Ukrainian]

Landré, A. Cornu, S., Meunier, J. D., Guérin, A., Arrouays, D., Caubet, M.,

Saby, N. P. A. (2020). Do climate and land use affect the pool of total silicon concentration? A digital soil mapping approach of French topsoils. Geoderma, 364, 114-175

Lozynskyi, V., Medianyk, V., Saik, P., Rysbekov, K., Demydov, M. (2020). Multivariance solutions for designing new levels of coal mines. Rudarsko Geolosko Naftni Zbornik, 35(2), 23-32. https://doi.org/10.17794/rgn.2020.2.3

Mank, V., Tonkha, O., Galimova, V., Surovtsev, S., Menshov, O., Bukova, O., Rogovskiy, I. (2019). Electrochemical investigation of cobalt absorbtion processes by soils of Ukraine Visnyk of Taras Shevchenko National University of Kyiv. Geology, 86(3), 34-39.

Matychenkov, V.V. (2008). The role of mobile silicon compounds in plants and the soil-plant system. Extended abstract ... Doctor's thesis(Biol. Sci.). Pushchino. [in Russian]

Menshov, O., Spassov, S., Camps, P., Vyzhva, S., Pereira, P., Pastushenko, T., \&Demidov, V. (2020). Soil and dust magnetism in semiurban area Truskavets, Ukraine. Environmental Earth Sciences, 79, 1-10.

Menshov, O., Kruglov, O., Vyzhva, S., Nazarok, P., Pereira, P. and Pastushenko, T. (2018) Magnetic methods in tracing soil erosion, Kharkov Region Ukraine. Stud. Geophys. Geod., 62, 681-696.

Menshov O. Sukhorada A. (2017). Basic theory and methodology of soil geophysics: the first results of application. Visnyk of Taras Shevchenko National University of Kyiv. Geology, 79(4), 35-39. [in Ukrainian]

Menshov O., Kuderavets R., Popov S., Homenko R., Sukhorada A., Chobotok I. (2016). Thermomagnetic analyzes of soils from the hydrocarbon fields. VisnykofTarasShevchenkoNationalUniversityofKyiv. Geology, 73(2), 33-37. [in Ukrainian]

Menshov, O.I. (2016). Magnetic method applying for the control of productive land degradation. Geofizicheskiy Zhurnal, 38(4), 130-137. [in Ukrainian]

Palianytsia, B., Kulik, T., Dudik, O., Cherniavska, T., Tonkha, O. (2014). Study of the thermal decomposition of some components of biomass by desorption mass spectrometry. International Congress on Energy Efficiency and Energy Related Materials (ENEFM2013), Springer, Cham, 19-25.

Ranjbar, S.S., Motesharezadeh, B., Moshiri, F., Hosseini, H.M., Alikhani, H.A. (2019). Silicon Utilization Efficiency of Different Wheat Cultivars in a Calcareous Soil. Silicon, 11(4), 2159-2168.

Rios, J.J., Martinez-Ballesta, M.C., Ruiz, J.M., Blasco, B., Carvajal, M. (2017). Silicon-mediated improvement in plant salinity tolerance: the role of aquaporins. Frontiers in plant science, 8, 948

Tabachenko, M., Saik, P., Lozynskyi, V., Falshtynskyi, V., Dychkovskyi, R. (2016). Features of setting up a complex, combined and zero-waste gasifier plant. Mining of Mineral Deposits, 10(3), 37-45. http://dx.doi.org/10.15407/ mining10.03.037

Titova, V.I., Dabahova, E.V., Dabahov, M.V. (2011). Agro- and biochemical methods of investigation of agroecosystems stage. N. Novgorod, 73-84. (in Russian).

Tonkha, O.L., Balayev, A.D., Pikovska,O.V. (2017). Formuvannya mikrobnoho kompleksu chornozemu rehradovanoho za riznykh system udobrennya. Naukovyy visnyk NUBiP. Seriya Ahronomiya, 269, 148-153. [in Ukrainian]

Tonkha, O.L. Sychevskyi, S.O., Pikovskaya, O.V., Kovalenko, V.P. (2018). Modern Approach In Farming Based On Estimation Of Soil Properties Variability. 12th International Conference on Monitoring of Geological Processes and Ecological Condition of the Environment

Надійшла до редколегії 25.05.20

О. Тонха ${ }^{1}$, д-р с.-г. наук, проф.,

E-mail: oksana16095@gmail.com

О. Бикова², зав. лаб.;

О. Піковська', канд. с-г. наук, доц.

І. Федосій ${ }^{1}$, канд. С-г. наук, доц.;

О. Меньшов ${ }^{3}$, д-р геол. наук, старш. наук. співроб.,

E-mail: menshov.o@ukr.net;

А. Шепель ${ }^{4}$, канд. с-г. наук, доц.;

${ }^{1}$ Національний університет біоресурсів і природокористування України, вул. Героїв оборони, 17, Київ, 03041, Україна;

${ }^{2}$ ТОВ Лотівка-Еліт, Хмельницький, Україна;

${ }^{3}$ Київський національний університет імені Тараса Шевченка,

ННІ "Інститут Геології", вул. Васильківська, 90, Київ, 03022, Україна,

${ }^{4}$ Херсонський державний аграрний університет, Херсон, Україна

\section{ВМІСТ КРЕМНІЮ ТА ФІЗИКО-ХІМІЧНІ ВЛАСТИВОСТІ ГРУНТІВ ХМЕЛЬНИЦЬКОЇ ОБЛАСТІ}

Кремній відіграє важливу роль у рості й розвитку рослин, їхньої стійкості до стресових умов. Однак дослідження вмісту різних форм кремнію в ґрунтах, їхнього взаємозв'язку з катіонами ґрунтів обмежені, що особливо актуально в контексті інтенсивного сільського господарства та аридизації клімату в Україні. Метою представленого дослідження було визначення вмісту сполук кремнію різної рухомості в орних ґрунтах Хмельницької області, ідентифікація просторових змін цих параметрів, а також виявлення залежності між вмістом сполук кремнію і розміром частинок ґрунту. Дослідження проводилося на ділянці ТОВ "Лотівка Еліт" Шепетівського району Хмельницької області в польовій сівозміні. Для зразків ґрунту були визначені: розподіл часток за розмірами, вміст фракцій різного гранулометричного складу для різних елементів, рН екстракції солі (1,0 М розчин КСІ), вміст гумусу, кальцій і магній обмінних сполук при екстракції 1,0 М розчину КСІ. Результати показали, що вміст сполук кремнію в ґрунтах залежить від гранулометричного складу, величини обмінної кислотності, вмісту гумусу і складу обмінних катіонів. У ґрунті кремній, екстрагований 0,1 М HCl, залежить від особливостей мікрорельєфу, може бути індикатором накопичувальних та ерозійних процесів і є параметром, який змінюється інтенсивніше порівняно з гранулометричним складом і вмістом катіонів обмінного кальцію і магнію.

Ключові слова: кремній, катіони ґрунтів, реакція ґрунтів, обмінні катіони, текстура ґрунтів. 
О. Тонха' ${ }^{1}$, д-р c.-х. наук, проф.,

E-mail: oksana16095@gmail.com;

О. Быкова ${ }^{2}$, зав. лаб.;

Е. Пиковская ${ }^{1}$, канд. С-х. наук, доц.

И. Федосий', канд. с-х. наук, доц.;

А. Меньшов ${ }^{3}$, А-р геол. наук, ст. науч. сотр.,

E-mail: menshov.o@ukr.net;

А. Шепель ${ }^{4}$, канд. с-х. наук, доц.;

${ }^{1}$ Национальний университет биоресурсов и природопользования Украины,

ул. Героев обороны, 17, Киев, 03041, Украина;

${ }^{2}$ ТОВ Лотовка-Элит, Хмельницкий, Украина;

${ }^{3}$ Киевский национальный университет имени Тараса Шевченко,

УнИ "Институт геологии", ул. Васильковская, 90, Киев, 03022, Украина;

${ }^{4}$ Херсонский государственный аграрный университет, Херсон, Украина

\section{СОДЕРЖАНИЕ КРЕМНИЯ И ФИЗИКО-ХИМИЧЕСКИЕ СВОЙСТВА ПОЧВ ХМЕЛЬНИЦКОЙ ОБЛАСТИ УКРАИНЫ}

Кремний играет важную роль в росте и развитии растений, их устойчивости к стрессовым условиям. Однако исследования содержания различных форм кремния в почвах, их взаимосвязи с катионами почв ограничены, что особенно актуально в контексте интенсивного сельского хозяйства и аридизации климата в Украине. Целью настоящего исследования было определение содержания соединений кремния различной подвижности в пахотных почвах Хмельницкой области, пространственное изменение этих параметров, а также выявление зависимости между содержанием соединений кремния и размером частиц почвы. Исследование проводилось на ров, а также выявление зависимости между содержанием соединений кремния и размером частиц почвы. Исследование проводилось на лены: распределение частиц по размерам, содержание фракций разного гранулометрического состава для различных элементов, рН экстракции соли (1,0 M раствор KCl), содержание гумуса, кальций и магний обменных соединений при экстракции 1,0 М раствора КСІ. Результаты показали, что содержание соединений кремния в почвах зависит от гранулометрического состава почвы, величины обменной кислотности, содержания гумуса и состава обменных катионов. В почве кремний, экстрагированный 0,1 M НСІ, зависит от особенностей микрорельефа, может быть индикатором накопительных и эрозионных процессов и является параметром, который изменяется более интенсивно по сравнению с гранулометрическим составом и содержанием катионов обменного кальция и магния.

Ключевые слова: кремний, катионы почвы, реакция почвы, обменные катионы, текстура почвы. 